\title{
HUBUNGAN MINAT BELAJAR TERHADAP HASIL BELAJAR METEMATIKA SISWA KELAS XI SMA NEGERI 1 LADONGI
}

\author{
Murtini $^{1)}$, Gusti Artika ${ }^{2)}$ \\ ${ }^{1,2)}$ SMA Negeri 1 Ladongi. Email: murtinimath.021@gmail.com ${ }^{1)}$,gustiartika4@gmail.com ${ }^{2)}$
}

\begin{abstract}
Abstrak
Penelitian ini adalah penelitian ex post facto yang bertujuan untuk melihat apakah ada hubungan antara minat belajar dengan hasil belajar siswa kelas XI SMA Negeri 1 Ladongi.Populasi dalam penelitian ini adalah seluruh siswa kelas XI SMA Negeri 1 Ladongi tahun pelajaran 2020/2021 yang tersebar dalam 7 kelas. Penentuan sampel dilakukan dengan teknik proportional random samplingdengan cara memilih sembilan siswa dari setiap kelas sebagai sampel penelitian. Teknik pengumpulan data menggunakan angket minat belajar dan dokumentasi untuk data hasil belajar matematika. Secara deskripsif diperoleh siswa yang minat belajarnya baik sebanyak 52 siswa atau $82,54 \%$, siswa yang minat belajarnya kurang sebanyak 11 siswa atau $17,46 \%$, siswa yang hasil belajar matematikanya baik sebesar 59 siswa atau 93,66\% dan siswa yang hasil belajar matematikanya kurang sebesar 4 siswa atau 6,34\%. Secara inferensial diperoleh terdapat hubungan yang positif dan signifikan antara minat belajar dengan hasil belajar matematika siswa kelas XI SMA Negeri 1 Ladongi.
\end{abstract}

Kata Kunci: hasil belajar matematika, minat belajar, pembelajaran matematika

\section{THE RELATIONSHIP OF LEARNING INTERESTS AND STUDENTS' MATHEMATICS LEARNING OUTCOMESOF CLASS XISMA NEGERI 1 LADONGI}

\begin{abstract}
This reseach is ex post facto reseach that aimed to find out is there any relationship of learning interests and students' learning outcomes of class XI SMA Negeri 1Ladongi. The population in this study were all students of class XI SMA Negeril Ladongi academic year 2020/2021, which is spread in 7 classes. Sample determination were taken by using proportional random samplingwith selected nine the students.The data collection technique used learning interests questionnaire anddocumentation for data of mathematics learning outcomes. Descriptively, students with good interest in learning were 52 studentsor $82.54 \%$, students with less interest in learning were 11 students or $17.46 \%$, students with good mathematics learning outcomes were 59 students or $93.66 \%$, students with less mathematics learning outcomes were 4 students or $6.34 \%$. Inferentially there is a positive and significant relationship between learning interests and students' mathematics learning outcomes class XI SMA Negeri 1 Ladongi.
\end{abstract}

Keywords: mathematics learning outcomes, learning interest, mathematics learning 


\section{Pendahuluan}

Perkembangan ilmu pengetahuan dan teknologi membuat pendidikan tidak dapat dipisahkan dari kehidupan manusia karena melalui pendidikan manusia dapat mencapai masa depan yang lebih baik. Hingga tak heran setiap negara dibelahan dunia berlomba-lomba untuk memperbaiki sistem pendidikannya.Sistem pendidikan di Indonesia mendapat sorotan tajam, dikarenakan masih terdapat permasaahan-permasalahan yang hingga saat ini masih dihadapi bersama.Salah satunya yakni rendahnya mutu atau kualitas pendidikan.Kualitas pendidikan sangat dipengaruhi dari pencapaian hasil belajar siswa, dimana hasil belajar siswa menjadi sebuah tolak ukur untuk menilai keberhasilan pendidikan disuatu sekolah.

Pada kurikuluam 2013 siswa dituntut mampu berpikir secara cerdas, aktif, kreatif, terampil, produktif, serta bertanggung jawab.Kemampuan yang harus dimiliki siswa ini diimplemantasikan pada beberapa mata pelajaran dalam pendidikan formal, salah satu mata pelajaran dalam pendidikan formal tersebut adalah matematika.

Guru memiliki peranan penting dalam proses belajar mengajar, karena guru merupakan orang yang secara langsung yang memberi materi pelajaran kepada siswa. Guru harus mampu menerapkan metode mengajar yang tepat dan melibatkan siswa secara aktif. Siswa merupakan individu yang secara langsung melakukan proses pembelajaran, sehingga siswa harus dapat mengikuti kegiatan pembelajaran dengan aktif dan mampu mengungkapkan gagasan-gagasan serta segala aspek yang ada pada dirinya baik kecerdasan, minat, perhatian, motivasi, cara belajar, dan disiplin belajar, sehingga akan mencapai hasil belajar yang memuaskan.

Keberhasilan belajar siswa sangat bergantung pada keterlibatan menyeluruh antara siswa. Kegiatan belajar akan berlangsung optimal jika siswa mengikuti seluruh rangkaian kegiatan secara utuh. Berhasil atau tidaknya proses belajar mengajar matematika dapat diukur melalui hasil belajar matematika siswa, jika hasil belajar matematika siswa cenderung baik tentunya memberi pengertian bahwa proses pembelajaran telah berjalan baik. Dan begitu juga sebaliknya jika hasil belajar matematika mahasiswa cenderung buruk tentunya proses belajar mengajar telah mengalami kendala. Hasil belajar siswa mencakup tiga ranah yaitu ranah kognitif, afektif dan psikomotorik.Mengingat pentingnya hasil belajar yang menunjukan ukuran keberhasilan siswa dalam dunia pendidikan, maka siswa diharapkan untuk senantiasa memperoleh hasil belajar yang optimal.Untuk mencapai hasil belajar yang optimal banyak faktor yang terlibat di dalamnya. Beberapa diantaranya adalah faktor kurikulum, guru, alat atau media, lingkungan, orang tua dan siswa itu sendiri.

Terdapat faktor dominan yang mempengaruhi hasil belajar siswa, faktor itu adalah minat belajar siswa. Minat besar pengaruhnya terhadap belajar karena jika pelajaran yang dipelajari tidak sesuai dengan minat siswa, siswa tidak akan belajar dengan sebaik-baiknya. Seorang siswa yang mempunyai keinginan terhadap sesuatu pelajaran maka akan merangsang timbulnya ketertarikan atau minat untuk melakukan pelajaran tersebut sehingga kegiatan belajar dapat berjalan dengan baik (Aritonang, 2008:14).

Dukungan minat belajar sangat dibutuhkan untuk terciptanya pembelajaran efektif. Siswa yang pada awalnya tidak mampu menguasai matematika, akan berusaha mengejar ketertinggalannya jika dalam diri siswa terbentuk minat tinggi untuk turut aktif dalam setiap proses pembelajaran, karena ia merasa puas dengan proses belajar. Sehingga minat belajar secara langsung dapat merubah perilaku belajar, dari tidak peduli menjadi lebih peduli. Yang dengan minat belajar tersebut siswa akan bersedia meninggalkan kegiatan yang kurang mendukung pencapai tujuan belajar. Pengembangan minat belajar tidak akan tumbuh tanpa adanya dukungan faktor pemicu yang mampu mempengaruhi nurani siswa. Faktor pemicu yang dapat berperan mengembangkan minat belajar siswa adalah waktu belajar, jika waktu belajar sesuai maka dapat meningkatkan minat belajar siswa sehingga proses belajar lebih efektif dan dapat meningkatkan hasil belajar matematika (Lestari, 2013:117).

Berdasarkan informasi yang diperoleh dari laporan lembaga internasional, perkembangan pendidikan di indonesia masih tergolong rendah. Terbukti dari hasil penelitian Programme for International Student Assesment (PISA) 2012 yang di tulis dalam PISA 2012 Result in Focus,bahwa dari 65 negera, indonesia menempati urutan ke-64 dengan rata-rata skor 
matematika siswa indonesia 375 , rata-rata skor membaca 396, dan rata-rata skor sains 382. Kenyataan dalam studi PISA tersebut menunjukan bahwa pendidikan di indonesia pada beberappa mata pelajaran belum berjalan sesuai harapan, Salah satunya yaitu mata pelajaran matematika.

Berdasarkan interaksi dengan salah seorang guru matematika diperoleh informasi bahwa hasil belajar siswa yang dilihat menunjukan hasil belajar siswa kurang. Hal ini karena masih terdapat beberapa masalah ketika proses belajar mengajar berlangsung salah satunya yaitu minat siswa dalam mengikuti proses pembelajaran kurang, seperti kurangnya tingkat partisipasi siswa dalam proses pembelajaran, saat guru sedang mengajukan pertanyaan, hanya beberapa siswa yang menjawab pertanyaan guru, perhatian siswa yang rendah membuat siswa tidak dapat fokus dalam menerima isi materi pembelajaran.

Untuk informasi tambahan, dilakaukan obeservasi dan memberikan lembar wawancara kepadasiswa diperoleh minat siswa dalam pembelajaran matematika kurang. Hal ini dilihat pada aktivitas siswa dalam kelas, ada beberapa siswa pada saat guru menjelaskan siswa tersebut tidak memperhatikan penjelasan guru, ada juga siswa yang terlihat tidak senang dengan materi yang dipelajari. Serta hasil dari lembar wawancara yang diberikan diperoleh tidak jarang siswa memandang matematika sebagai pelajaran yang sulit bahkan ada siswa yang menganggap bahwa matematika adalah kegiatan pembelajaran yang membosankan, beberapa siswa juga tidak aktif dalam melakukan pembelajaran baik di rumah maupun di sekolah, Permasalahan tersebut menyebabkan hasil belajar matematika siswa rendah.

Berdasarkan laporan lembaga internasional, perkembangan pendidikan di indonesia masih tergolong rendah. Terbukti dari hasil penelitian Programme for International Student Assesment (PISA) 2012 yang di tulis dalam PISA 2012 Result in Focus, bahwa dari 65 negera, indonesia menempati urutan ke-64 dengan rata-rata skor matematika siswa indonesia 375, rata-rata skor membaca 396, dan rata-rata skor sains 382 . Kenyataan dalam studi PISA tersebut menunjukan bahwa pendidikan di indonesia pada beberappa mata pelajaran belum berjalan sesuai harapan, Salah satunya yaitu mata pelajaran matematika (Sughiarti, 2016:4).
Ini didukung dengan penelitian yang dilakukan sebelumnya yaitu penelitian yang telah dilakukan oleh Sari, Rakimahwati, dan Fitria di SDN 25 Jati Tanah Tinggi yang memperoleh hasil bahwa minat belajar dan hasil belajar memiliki hubungan yang signifikan dengan nilai signifikansi sebesar 0,000 dan besar hubungan antara minat belajar dan hasil belajar sebesar $53,29 \%$. Juga penelitian yang telah dilakukan oleh Fajriani di SMP Negeri 3 Sawit yang memperoleh hasil bahwa minat belajar memberikan kontribusi yang positif terhadap hasil belajar dengan nilai signifikansi sebesar 0,000 dan besar hubungan minat belajar dengan hasil belajar adalah 52,2\%.

Hal inilah yang mendorong penulis ingin melakukan sebuah penelitian yang berjudul Hubungan Minat Belajar Terhadap Hasil Belajar Matematika Siswa Kelas XI SMA Negeri 1 Ladongi.

Belajar berarti suatu proses menambah, mengkontriksi pengetahuan seseorang yang mengakibatkan perubahan prilaku yang dihasilkan dari pengalaman masa lalu maupun dari pembelajaran yang bertujuan atau di rencanakan serta kegiatan belajar ini tidak pernah dibatasi usia, tempat maupun waktu. Perubahan tingkah laku yang terjadi berkaitan dengan ilmu pengetahuan, sikap, minat, watak dan penyesuaian diri.

Mayer mengemukakan pendapat bahwa belajar berkembang dalam tiga pandangan. Kegitga pandangan tersebut yaitu : (1) belajar terjadi jika seseorng memperkuat atau memperlemah hubungan antara stimulus dan respon. (2) belajar merupakan penambahan pengetahuan, karena ketika seseorang belajar ia berusaha menempatkan informasi kedalam memori jangka panjang(long-term memory). (3) belajar adalah proses mengkontruksi pengetahuan, karena ketika seseorang belajar ia aktif mengkontruksi pengetahuan dalam " working memory" (Gasong, 2018:13).

Proses pembelajaran pada hakikatnya merupakan proses interaksi peserta didik dengn pendidik dan sumber belajar pasa suatu lingkungan belajar. Pembelajaran merupakan bantuan yang diberikan pendidik agar dapat terjadi proses perolehan ilmu dan pengetahuan, penguasaan kemahiran, serta pembentukan sikap dan kepercayaan pada peserta didik. Dengan kata lain, pembelajaran adalah proses untuk membantu peserta didik agar dapat belajar dengan baik (Suardi, 2018:7). 
Matematika merupakan ilmu universal yang menjadi dasar perkembangan teknologi modern, mempunyai peran penting dalam berbagai disiplin ilmu dan daya pikir manusia (Depdiknas, 2006).Selama ini matematika dianggap sebagai pelajaran yang sulit oleh sebagian besar siswa.Anggapan demikian tidak lepas dari persepsi yang berkembang dalam masyarakattentang matematika. Hal ini berimbas kepada rendahnya hasil belajar siswa yang disebabkan tidak adanya minat dalam mempelajari mata pelajaran matematika(Sriyanto,2017:22).

Pembelajaran matematika merupakan kombinasi fungsional antara siswa dengan guru dan siswa dengan siswa dalam rangka perubahan sikap dan pola pikir agar siswa memiliki kemampuan, pengetahuan dan keterampilan matematis yang bertujuan mempersiapkan siswa menghadapi perubahan yang selalu berkembang (Faradisa, Sulistio, \& Ayu, 2018:169). Pembelajaran matematika adalah proses pemberian pengalaman belajar kepada peerta didik melalui serangkaian kegiatan yang terencana sehingga peserta didik memperoleh pengetahuan tentang matematika yang dipelajari, cerdas, terampil, mampu memahami dengan baik bahan yang diajarkan (Amir, 2014: 73).

Hasil belajar pada dasarnya adalah hasil akhir yang diharapkan dapat dicapai setelah sesorang belajar. Untuk memperoleeh hasil belajar, dilakukan evaluasi atau penilaian yang merupakan tindak lanjut atau cara untuk mengukur tingkat penguasaan siswa. Kemajuan hasil belajar siswa tidak hanya diukur dari tingkat penguasaan ilmu pengetahuan tetapi juga sikap dan keterampilan.Dengan demikian, penilaian hasil belajar siswa mencangkup segala hal yang dipelajari di sekolah, baik itu mencangkup pengetahuan, sikap dan keterampilan (Jihad, 2012:15).

Hasil belajar matematika adalah kemampuan yang dimiliki siswa yang diperoleh dari proses pembelajaran matematika yang berupa perubahan dalam bentuk kognitif, afektif, dan psikomotor yang di ukur dalam suatu tes dan kemudian di akumulasikan dalam bentuk skor berupa angka atau simbol.

Terdapat beberapa faktor-faktor yang mempengaruhi hasil belajar, tetapi dapat digolongkan menjadi dua yaitu faktor intern dan faktor ekstern. Faktor intern merupakan faktor yang berasal dari diri siswa itu sendiri, antara lain minat belajar, aktivitas belajar, sikap siswa terhadap pelajaran, intelegensi, motivasi, kebiasaan, dan bakat. Faktor ekstern adalah faktor yang berasal darai luar diri siswa, misalnya fasilitas belajar, situasi kelas, dukungan orang tua, dan lingkungan belajar. (Slameto, 2003:54),

Wahab (2015:26-31) mengemukakan bahwa faktor-faktor yang mempengaruhi hasil belajar antara lain meliputi faktor internal dan faktor eksternal sebagai berikut:

a. Faktor internal adalah faktor-faktor yang berasal dari dalam diri individu dan dapat mempengaruhi hasil belajar individu. Faktor-faktor internal ini meliputi: 1) Faktor fisiologis yang didalamnya mencangkup: Keadaan tonus jasmani, pada umumnya sangat mempengaruhi aktivitas belajar seseorang. Kondisi fisik yang sehat dan bugar akan memberikan pengaruh positif terhadap kegiatan belajar individu begitupula sebaliknya, kondisifisik yang lemah atau sakit akan menghambat tercapainya hasil belajar yang maksimal. Dan keadaan fungsi jasmani/fisiologis, Selama proses belajar berlangsung, peran fungsi fisiologis pada tubuh manusia sangat mempengaruhi hasil belajar, tertutama pancaindra. Pancaindra yang berfungsi dengan baik akan mempermudah aktivitas belajar dengan baik pula. 2) Faktor psikologis yang didalmnya mencangkup: Kecerdasan/intelegensi siswa, pada umumnya kecerdasan diartikan sebagai kemampuan psikofisik dalam mereaksi rangsangan atau menyesuaikan diri dengan lingkungan melalui cara yang tepat. Motivasi adalah salah satu faktor yang mempengaruhi keefektifan kegiatan belajar siswa. Minat (interest) berarti kecenderungan dan kegairahan yang tinggi atau keinginan yang besar terhadap sesuatu. Sikap adalah gejala internal yang berdimensi afektif berupa kecenderungan untuk mereaksi atau merespon dengan cara relatif terhadap objek, orang, peristiwa dan sebagainya baik secara positif maupun negatif. Bakat (aptitude) didefinisikan sebagai kemampuan potensial yang dimiliki seseorang untuk mencapai keberhasilan pada masa yang akan datang.

b. Faktor eksternal meliputi: 1) Lingkungan sosial yang didalamnya mencangkup: Lingkungan sosial masyarakat, kondisi 
lingkungan masyarakat tempat tinggal siswa akan mempengaruhi belajar. Lingkungan siswa yang kumuh, banyak pengangguran dan anak terlantar juga dapat mempengaruhi aktivitas belajar siswa, paling tidak kesulitan ketika memerlukan teman belajar, diskusi atau meminjam alat-alat belajar yang kebetulan belum dimilikinya.Lingkungan sosial keluarga, lingkungan ini sangat mempengaruhi kegiatan belajar, ketegangan keluarga, sifat-sifat orng tua, demografi keluarga (letak rumah), pengelolaan keluarga semuanya dapat. Lingkungan sosial sekolah seperti guru, administrasi, dan teman-teman dapat mempengaruhi proses belajar seorang siswa. Hubungan yang harmonis antara ketiganya dapat menjadi motivasi bagi siswa untuk belajar lebih baik disekolah. 2) Lingkungan nonsosial yang didalamnya mencangkup:: Lingkungan alamiah merupakan faktor-faktor yang dapat mempengaruhi aktivitas belajar siswa. Sebaliknya, bila kondisi lingkungan alam tidak mendukung, proses belajar siswa akan terhambat. 3) Faktor instrumental yaitu perangkat belajar yang digolongkan dua macam. Pertama, hadware (perangkat keras), seperti gedung sekolah, alat-alat belajar, fasilitas belajar, lapangan olahraga, dan lain sebagainya. Kedua, software (perangkat lunak), seperti kurikulum sekolah, peraturan-peraturan sekolah, silabus dan lain sebagainya.

B.S Bloom mengemukakan bahwa terdapat tiga ranah hasil belajar yaitu ranah kognitif, ranah afektif dan ranah psikomotorik yang dirinci sebagai berikut:

a. Ranah Kognitif, berkenaan dengan hasil belajar intelektual yang terdiri dari enam aspek yaitu pengetahuan atau ingatan, pemahaman aplikasi, analisis, evaluasi dan sintesis (kreatif).

b. Ranah Afektif, berkenaan dengan sikap yang terdiri dari lima aspek yaitu penerimaan, jawaban atau reaksi, penilaian, organisasi, dan internalisasi.

c. Ranah Psikomotorik, berkenaan dengan hasil belajar keterampilan dan kemampuan bertindak yang terditi dari enam aspek yaitu gerakan refleks, keterampilan gerakan dasar, kemampuan perseptual, keharmonisan atau ketepatan, gerakan keterampilan kompleks, dan gerkan ekspresif dan interpretatif. (Wahyuningsih, 2020:66-68)
Minat merupakan perasaan yang mendorong seseorang untuk melakukan suatu kegiatan atau dorongan yang melatar belakangi seseorang melakukan sesuatu. Dengan kata lain, minat belajar adalah dorongan yang dimiliki seseorang untuk melakukan kegiatan belajar (Rusmiati, 2017:23). Menurut Guilfort, minat belajar adalah dorongan-dorongan dari dalam diri siswa secara psikis dalam mempelajari sesuatu dengan penuh kesadaran, ketenangan, kedisiplinan (Lestari \& Yudhanegara, 2015:93). Sehingga diperoleh minat belajar adalah keinginan yang muncul dari dorongan dalam diri sendiri untuk belajar tanpa ada paksaan dari orang lain dan merasa senang saat melakukan hal tersebut.

Setiap orang mempunyai tingkatan minat yang berbeda-beda terhadap sesuatu hal. Tetapi minat seseorang dapat ditumbuhkan dengan berbagai cara, salah satu cara membangkitkan minat siswa yaitu dengan membangung sikap positif. Perasaan senang akan menimbulkan minat pula, yang di perkuat lagi oleh sikap positif. Sikap positif yang dimaksud antara lain yaitu salah satunya guru memberikan hal-hal yang membangun pikiran siswa yang positif (baik) sehingga siswa akan melakukan hal hal yang positif baik terhadap diri sendri maupun orang lain.

Ada beberapa indikator dalam minat belajar. Safari mengemukakan bahwa ada empat indikator siswa yang memiliki minat belajar, yaitu:

1) Perasaan Senang, seorang siswa yang memiliki perasaan senang atau suka terhadap suatu mata pelajaran, maka siswa tersebut akan terus mempelajari ilmu yang disenanginya. Tidak ada perasaan terpaksa pada siswa untuk mempelajari bidang tersebut.

2) Ketertarikan Siswa, berhubungan dengan daya gerak yang mendorong untuk cenderung merasa tertarik pada orang, benda, kegiatan atau bisa berupa pengalaman afektif yang dirangsang oleh kegiatan itu sendiri.

3) Perhatian Siswa, perhatian merupakan konsentrasi atau aktivitas jiwa terhadap pengamatan dan pengertian, dengan mengesampingkan yang lain. Siswa yang memiliki minat pada objek tertentu, dengan sendirinya akanmemperhatikan objek tersebut. 
4) Keterlibatan Siswa, ketertarikan seseorang akan suatu objek yang mengakibatkan orang tersebut senang dan tertarik untuk melakukan atau mengerjakan kegiatan dari objek tersebut

(Sidik, 2015:53).

Minat memiliki peran yang sangat penting dalam proses belajar karena minat menjadi salah satu faktor penentu dalam berhasil atau tidaknya tujuan pengajar yang akan dicapai. Siswa yang tidak berminat terhadap bahan pelajaran akan menunjukkan sikap kurang simpatik, malas dan tidak bergairah mengikuti proses belajar mengajar. Untuk merangsang perhatian siswa setiap guru dituntut harus mampu menarik perhatian siswa terhadap apa yang diberikan. Suatu keadaan yang menarik perhatian siswa diharapkan dapat menimbulkan minat belajar siswa. Apabila anak didik menunjukkan minat belajar yang rendah adalah tugas pendidik disamping orang tua untuk meningkatkan minat tersebut, sebab jika pendidik mengabaikan minat belajar anak akan mengakibatkan tidak berhasilnya dalam proses belajar mengajar (Fajriani, 2017:4).

Minat dapat mempengaruhi kualitas pencapaian hasil belajar siswa dengan memunculkan perasaan senang. Misalnya, seorang siswa yang menaruh minat besar terhadap matematika akan merasa senang melakukan pembelajarannya daripada siswa lainnya. Kemudian, karena perasaan yang senang muncul dalam diri siswa terhadap materi itulah yang memungkinkan siswa tadi untuk belajar lebih giat, dan akhirnya mencapai hasil belajar yang diinginkan (Syah, 2010:152).

Menurut Pangestu (2015:18), minat dapat mempengaruhi kualitas pencapaian hasil belajar siswa dengan memunculkan ketertarikan siswa pada pelajaran, karena bila pelajaran yang dipelajari tidak sesuai dengan minat siswa, maka siswa tidak akan belajar dengan sebaik-baiknya karena tidak ada daya tarik baginya. Ia tidak fokus untuk belajar, ia tidak memperoleh kepuasan dari pelajaran itu. Sebaliknya bahan pelajaran yang menarik minat siswa, lebih mudah dihafalkan dan disampaikan, karena minat menambah kegiatan belajar. Sehingga apabila minat belajar siswa tinggi pada akhirnya akan mencapai hasil belajar yang memuaskan.

Keterlibatan siswa secara aktif dalam proses belajar mengajar juga dapat mempengaruhi pencapaian hasil belajar, karena apabila siswa menunjukan keterlibatan yang aktif terhadap pelajaran akan memunculkan pemahaman siswa pada pelajaran yang diikuti sehingga siswa memiliki keinginan sendiri untuk melibatkan diri di proses pembelajaran dan pada akhirnya akan mencapai hasil belajar yang baik. Hal ini mengandung arti bahwa seseorang siswa akan sukar mencapai hasil belajar yang baik dan benar tanpa adanya minat (Arifin, 2018:60).

Djamarah dalam (Simbolon, 2014: 18) berpendapat bahwa ada beberapa macam cara yang dapat dilakukan oleh guru untuk membangkitkan minat belajar siswa yaitu:

1. Membandingkan adanya suatu kebutuhan pada diri siswa sehingga ia rela belajar tanpa paksaan.

2. Menghubungkan bahan pelajaran yang diberikan dengan persoalan pengalaman yang dimiliki siswa.

3. Memberikan kesempatan kepada siswa untuk mendapatkan hasil belajar yang baik dengan cara menyediakan lingkungan belajar yang kreatif dan kondusif.

4. Menggunakan berbagai macam bentuk dan teknik mengajar dalam konteks perbedaan individual siswa.

Emda (2017:179) juga mengatakan bahwa ada beberapa cara yang dapat dilakukan untuk menumbuhkan minat belajar siswa yaitu :

a. Hubungkan bahan pelajaran yang akan diajarkan dngan kebutuhan siswa.

b. Sesuaikan materi pelajaran dengan tingkat pengalaman dan kemampuan siswa.

c. Gunakan berbagai model dan strategi pembelajaran secara bervariasi.

\section{Metode}

Jenis penelitian ini adalah penelitian kuantitatif dengan pendekatan Ex Post Facto.Variabel pada penelitian ini terdiri atas satu variabel bebas yaitu tingkat minat belajar yang disimbolkan dengan $(X)$ dan satu variabel terikat yaitu hasil belajar matematika yang disimbolkan dengan (Y).Model hubungan variabel dalam penelitian ini adalah sebagai berikut:

Tabel 1 Desain Penelitian

dimana:

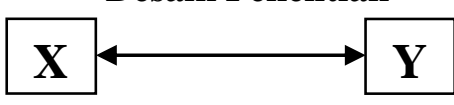

$\mathrm{X}$ :Minat belajar siswa kelas XI SMA Negeri 1 Ladong.

Y :Hasilbelajar matematika siswa kelas XI SMA Negeri 1 Ladongi. 
Populasi dalam penelitian ini adalah seluruh siswa kelas XI SMA Negeri 1 Ladongi pada tahun pelajaran 2020/2021 yang terdiri dari 7 kelas parallel dan berjumlah 250 siswa..Sampel dalam penelitian ini sebanyak 63 siswa.Penentuan sampel penelitian dilakukan dengan menggunakan teknik proportional random sampling.

Instrumen dalam penelitian ini terdiri instrumen minat belajar yaitu angket minat belajaryang diadopsi dari instrumen yang dibuat dan digunakan oleh Kusumawardani (2014:84) terdiri dari pernyataan 32 dengan menggunakan skala 1 sampai 4 dan instrumen hasil belajar matematika yaitu hasil dari proses belajar yang diperoleh melalui evaluasi materi pelajaran yang diberikan oleh guru matape;ajaran matematika dalam hal ini setelah melalui proses belajar mengajar dalam waktu tertentu berupa nilai ulangan akhir semester ganjil pada mata pelajaran matematika.
Data yang diperoleh dalam penelitian ini berupa data hasil angket minat belajar dan data hasil belajar belajar matematika.Setelah data terkumpul dilakukan analisis data berupa analisis deskriptif dan analisis inferensial.

Analisis deskriptif digunakan untuk menggambarkan karakteristik distribusi masingmasing variabel (minat belajar dan hasil belajar matematika) yang terdiri atas mean, median, modus, standar deviasi, standar of mean, skewness, kurtosis, nilai minimum, nilaimaksimum dan grafik/gamba. Setelah melakukan analisis deskripsif selanjutnya masing-masing variabel (minat belajar dan hasil belajar matematika) dikategorikan menjadi 4 kategori. menurut Pusdiklat Pegawai (2016:56) pengkategorian minat belajar dibagi menjadi 4 , yaitu sangat berminat, berminat, kurang berminat dan tidak berminat dengan penentuan interval menggunakan rumus yaitu skor maximal-skor minimal

Tabel 2

Pengkategorian Minat Belajar Siswa

\begin{tabular}{cc}
\hline Interval & Kategori \\
\hline $104 \leq X \leq 128$ & Sangat Berminat \\
\hline $80 \leq X<104$ & Berminat \\
\hline $56 \leq X<80$ & Kurang Berminat \\
\hline $32 \leq X<56$ & Tidak Berminat \\
\hline
\end{tabular}

Keterangan :

$\mathrm{Y}=$ Nilai Hasil Belajar Siswa
Dan menurut Ditjen Dikdasmen (2017:11) pengkategorian hasil belajar di bagi menjadi 4 kategori yaitu sangat baik, baik, cukup, dan kurang.

Tabel 3

Pengkategorian Hasil Belajar Matematika Siswa

\begin{tabular}{cc}
\hline Interval & Kategori \\
\hline $85<Y \leq 100$ & Sangat Baik \\
\hline $70<Y \leq 85$ & Baik \\
\hline $55<Y \leq 70$ & Cukup \\
\hline$Y \leq 55$ & Kurang
\end{tabular}

Keterangan :

$\mathrm{Y}=$ Nilai Hasil Belajar Siswa

Analisis inferensial digunakan untuk pengujian hipotesis penelitian dengan prosedur uji normalitas terlebih dahulu.Uji normalitas data ini dimaksudkan untuk mengetahui apakah data yang diperoleh berasal dari populasi yang berdistribusi normal atau tidak.Apabila data yang diperoleh berdistribusi normal maka analisis dapat di lanjutkan dan data dapat digunakan untuk analisis berikutnnya.Untuk keperluan ini, maka statistik yang digunakan adalah uji Kolmogorov Smirnovdengan menggunakan bantuan SPSS. Selanjutnya dilakukan uji hipotesis, pada uji hipotesis ini menggunakanuji signifikasi koefisien korelasi $\mathrm{X}$ dan Yyang akanmelihat ada tidaknya hubungan, besarnya hubungan serta kuat tidaknya hubungan yang terjadi antara variabel minat 
belajar siswa $(\mathrm{X})$ dengan variabel hasil belajar matematika siswa $(\mathrm{Y})$

\section{Hasil}

\section{Hasil Analisis Deskriptif}

Hasil analisis deskriptif yang diperoleh dalam penelitian ini terdapat dua yaitu hasil analisis deskriptif minat belajar dan hasil analisis deskriptif hasil belajar matematika.

\section{Hasil Analisis Deskriptif Minat Belajar}

Hasil analisis deskriptif nilai angket minat belajar siswa menggunakan aplikasi $I B M$ SPSSStatistics dipeoleh data minat belajar siswa kelas XI SMA Negeri 1 Ladongi yang dapat dilihat pada table4 berikut.

Tabel 4

Deskripsi Minat Belajar Siswa

\begin{tabular}{lc}
\hline \multicolumn{1}{c}{ Statistik Deskriptif } & Sampel \\
\hline$N$ & 63 \\
\hline Mean & 89 \\
\hline Median & 91 \\
\hline Modus & 94 \\
\hline Std. Error of Mean & 1,301 \\
\hline Std. Deviation & 10,327 \\
\hline Skewness & $-0,657$ \\
\hline Kurtosis & 0,747 \\
\hline Minimum & 62 \\
\hline Maximum & 111
\end{tabular}

Berdasarkan tabel 4terlihat bahwa data sampel kelas XI SMA Negeri 1 Ladongi yang berjumlah 63 siswa memiliki nilai rata-rata sebesar 89 yang menunjukan bahwa nilai ratarata minat belajar siswa kelasXI SMA Negeri 1 Ladongi tergolong dalam kategori berminat, dapat dilihat sebaran data siswa mendekati nilai rata rata karena dilihat dari nilia standar deviasi yang kecil. Dilihat dari nilai skewness, sebaran

data terlihat condong ke arah kiri hal ini disebabkan karena nilai modus lebih besar daripada nilai mean. Sedangkan dilihar dari nilai kurtosis yang diperoleh, sebaran datanya memiliki distribusi platikurtik, dimana distribusi ini merupakan distribusi yang memiliki puncak mendatar.Distribusi frekuensi dan persentase minat belajar siswa kelas XI SMA Negeri 1 Ladongiselengkapnya dapat dilihat pada tabel 5.

Tabel 5

Distribusi Frekuensi dan Persentase Minat Belajar Siswa

\begin{tabular}{cccc}
\hline Kategori & Interval & Frekuensi & Persentase \\
\hline Sangat Berminat & $104 \leq X \leq 128$ & 6 & $9,53 \%$ \\
\hline Berminat & $80 \leq X<104$ & 46 & $73,01 \%$ \\
\hline Kurang Berminat & $56 \leq X<80$ & 11 & $17,46 \%$ \\
\hline Tidak Berminat & $32 \leq X<56$ & 0 & $0 \%$ \\
\hline
\end{tabular}

Tabel 5 Distribusi frekuensi dan persentasi minat belajar siswa kelas XI SMA Negeri 1 Ladongi menunjukkan sebaran data siswa yang berminat persentasenya lebih banyak dibandikan dengan yang lainnya, yaitu sebanyak $73 \%$ siswa di kelas XI yang tersebar dalam 7 kelas tersebut. Dimana hal ini menunjukan bahwa siswa di SMA Negeri 1 ladongi terkhusus di kelas XI memilliki siswa yang termasuk dalam kategori berminat.
Dalam indikator minat belajar biasa terdapat indikator yang dominan dan yang tidak dominan, indikator dominan dan tidak dominan inipeneliti memperolehnya dengan melihat indikator minat belajar yang dominan baik dan kurang baik dalam penelitian yang dikakukan dapat dilihat pada tabel 4 skor untuk setiap indikator yaitu antara lain: 
Tabel6

Skor Untuk Setiap Indikator Minat Belajar

\begin{tabular}{cllc}
\hline Variabel & \multicolumn{2}{c}{ Indiator Variabel } & JumlahSkor \\
\hline \multirow{3}{*}{$\begin{array}{c}\text { Minat } \\
\text { Belajar }\end{array}$} & 1. & Perasaan Senang & 1352 \\
\cline { 2 - 3 } & 2. & Ketertarikan Siswa & 1581 \\
\cline { 2 - 3 } & 3. & Perhatian Siswa & 1464 \\
\cline { 2 - 3 } & 4. & Keterlibatan Siswa & 1219 \\
\hline
\end{tabular}

Dari tabel 6 dapat dilihat bahwa siswa yang memilik indikatori minat belajar lebih dominan baik pada indikator ketertarikan siswa dan perhatian siswa, sedangkan siswa yang memilik indikatori minat belajar lebih dominan kurang pada indikator keterlibatan siswa dan perasaan senang

\section{Hasil Analisis Deskriptif Hasil Belajar Matematika}

Hasil analisis deskriptif nilai angket hasil belajar matematika siswa menggunakan aplikasi IBM SPSSStatistics dipeoleh data hasil belajar matematika siswa kelas XI SMA Negeri 1 Ladongi yang dapat dilihat pada tabel berikut:

Tabel 7

Deskripsi Hasil Belajar Matematika

\begin{tabular}{lc}
\hline \multicolumn{1}{c}{ Statistik Deskriptif } & Sampel \\
\hline$N$ & 63 \\
\hline Mean & 80,60 \\
\hline Median & 81 \\
\hline Modus & 80 \\
\hline Std. Error of Mean &, 895 \\
\hline Std. Deviation & 7,104 \\
\hline Skewness & $-1,751$ \\
\hline Kurtosis & 4,799 \\
\hline Minimum & 55 \\
\hline Maximum & 92 \\
\hline
\end{tabular}

Berdasarkan tabel 7 terlihat bahwa data sampel kelas XI SMA Negeri 1 Ladongi yang berjumlah 63 siswa memiliki nilai rata-rata sebesar 80,6 yang menunjukan bahwa nilai ratarata hasil belajar siswa kelasXI SMA Negeri 1 Ladongi tergolong dalam kategori baik, dapat dilihat sebaran data siswa mendekati nilai rata rata karena dilihat dari nilia standar deviasi yang kecil. Dilihat dari nilai skewness, sebaran data terlihat condong ke arah kanan hal ini disebabkan karena nilai modus lebih kecil dari pada nilai mean. Sedangkan dilihar dari nilai kurtosis yang diperoleh, sebaran datanya memiliki distribusi leptokurtik, dimana distribusi ini merupakan distribusi yang memiliki puncak relatif tinggi.Distribusi frekuensi dan persentase hasil belajar matematika siswa kelas XI SMA Negeri 1 Ladongiselengkapnya dapat dilihat pada tabel 8.

Tabel 8

Frekuensi dan Persentase Hasil Belajar Matematika

\begin{tabular}{cccc}
\hline Kategori & Interval & Frekuensi & Persentase \\
\hline Sangat Baik & $85<Y \leq 100$ & 11 & $17,46 \%$ \\
\hline Baik & $70<Y \leq 85$ & 48 & $76,2 \%$ \\
\hline Cukup & $55<Y \leq 70$ & 2 & $3,17 \%$ \\
\hline Kurang & $Y \leq 55$ & 2 & $3,17 \%$ \\
\hline
\end{tabular}


Tabel 8Distribusi frekuensi dan persentase hasil belajar matematika siswa kelas XI SMA Negeri 1 Ladongi menunjukkan sebaran data siswa yang termasuk dalam kategori persentasenya lebih banyak dibandikan dengan yang lainnya, dimana hal ini menunjukan bahwa siswa di SMA Negeri 1 ladongi terkhusus di kelas XI memilliki siswa yang termasuk dalam kategori hasil belajar yanng baik.

\section{Hasil Analisis Inferensial \\ Uji Normalitas}

Berikut tabel hasil uji normalitas data angket minat belajar menggunakan uji Kolmogorov-Smirnov dengan bantuan apliasi IBM SPSS Statistics.

Tabel 9

Hasil Uji Normalitas Data Minat Belajar Siswa

\begin{tabular}{ccc}
\hline Data Angket & Sig. & Keputusan \\
\hline Minat Belajar & 0,063 & Terima $\mathrm{H}_{0}$ \\
\hline
\end{tabular}

Berdasarkan hasil analisis uji normalitas data minat belajar diperoleh $\mathrm{H}_{0}$ di terima.Hal iniberarti bahwa data minat belajar berdistribusi normal berarti bahwa data minat belajar berdistribusi normal.
Berikut tabel hasil uji normalitas data angket Hasil Belajar Matematika yang menggunakanuji Kolmogorov-Smirnovdengan bantun aplikasi IBM SPSS Statistics.

Tabel 10

Hasil Uji Normalitas Data Hasil Belajar Matematika

\begin{tabular}{ccc}
\hline Data & Sig. & Keputusan \\
\hline Hasil Belajar Matematika & 0,061 & Terima $\mathrm{H}_{0}$ \\
\hline
\end{tabular}

Berdasarkan hasil analisis uji normalitas data hasil belajar matematika diperoleh nilai signifikansi sebesar 0,061. Karena nilai signifikansi $0,061>\alpha$ (dimana $\alpha=0,05$ ), maka $\mathrm{H}_{0}$ di terima. Hal ini berarti bahwa data hasil belajar matematika berdistribusi normal.

\section{Uji Hipotesis}

Hasil analisis hubungan minat belajar (X) terhadap hasil belajar matematika (Y) menggunakan aplikasi IBM SPSS Statistics dengan menggunakan uji signifikansi koefisisen korelasi.

Tabel 11

Hasil Uji Signifikansi Koefisien Korelasi Hasil Belajar Matematika dan Minat Belajar

\begin{tabular}{ccccc}
\hline $\mathbf{R}$ & R Square & F Change & Sig. F Change & Keputusan \\
\hline 0,687 & 0,471 & 54,399 & 0,000 & Tolak $\mathrm{H}_{0}$ \\
\hline
\end{tabular}

Berdasarkan hasil uji signifikan koefisien korelasi diperolah nilai signifikasi sebesar $0,000<\alpha$ (dimana $\alpha=0,05)$, maka $\mathrm{H}_{0}$ di tolak. Dengan demikian, koefisien korelasi $\mathrm{X}$ dan $\mathrm{Y}$ adalah berarti atau signifikan maksud dari signifikan ini yaitu minat belajar dan hasil belajar ini memiliki hubungan yang yaitu minat belajar jika mengalami peningkatan yang terus menerus maka hasil belajar juga akan naik begitu pula sebaliknya yaitu jika minat belajar yang diperoleh rendah maka akan berpengaruh pula pada hasil belajar siswa yang rendah pula sehingga akan lebih baik untuk memperhatikan minat siswa agar hasil belajar yang ingin diperoleeh tercapai,dan nilai $\mathrm{R}$ sebesar 0,687 yang menunjukan bahwa hubungan antara variabel $\mathrm{X}$ dan $\mathrm{Y}$ positif yaitu besar hubungan antra minat belajar dan hasil belajar yaitu termasuk dalam kategori kuat yaitu 47,1\% .

\section{Pembahasan}

Berdasarkan hasil analisis deskriptif minat belajar siswa kelas XI SMA Negeri 1 Ladongi menunjukan bahwa hasil perhitungan rata-rata minat belajar siswa tampak bahwa 
siswa yang mempunyai minat belajar yang baik yaitu yang tergolong dalam kategori berminat dan sangat berminat adalah sebanyak 52 siswa atau $82,54 \%$ dan siswa yang mempunyai minat belajar yang kurang yaitu yang tergolong dalam kategori kurang berminat dan tidak berminat adalah sebanyak 11 siswa atau 17,46\%. Hal ini sesuai dengan jawaban siswa dari angket yang diberikan yaitu perasan senang, ketertarikan, perhatian dan keterlibatan siswa terhadap pelajaran matematika lebih banyak yang memberikan skor jawaban yang tinggi.Karena berdasarkan data yang diperoleh yaitu siswa yang mempunyai minat belajar baik lebih banyak dari siswa yang mempunya minat belajar kurang sehingga secara umum dapat dikatakan bahwa siswa kelas XI SMA Negeri 1 Ladongi mempunyai minat belajar terhadap mata pelajaran matematika yang baik.

Dari keempat indikator minat belajar yang digunakan peneliti dan setelah mendapat data angket yang telah diini oleh siswa, terlihat bahwa minat belajar siswa pada indikator ketertarikan siswa dan perhatian siswa lebih baik dibandingkan dengan indikator keterlibatan siswa dan perasaan senang. Hal ini menunjukan bahwa siswa di SMA Negeri 1 Ladongi dalammemunculkan perasaan senang dan keterlibatannya dalam pembelajaran masih kurang sehingga guru harus lebih memperhatikan dua hal tersebut, dengan salah satu caranya yaitu selalu membuat siswa berfikiran positif, merubah pikiran siswa yang dari awalnya terlihat tidak tertarik dengan pelajaran matematika untuk membuat senang perasaannya, serta hal hal yang dapat memunculkan keiinginan siswa untuk terllibat langsung dalam kegiatan pembelajaran.Tetapi tidak mengabaikan dua indikator lainnya walaupun untuk saat ini masih lebih bagus di bandingkan dengan indikator keterlibatan siswa dan perasaan senang. Dua indikator ini agar juga lebih ditingkatkan dalam proses pembelajran agar mbghasilkan minat belajar siswa yang lebih baik lagi agar siswa memiliki keiinginan yanng besar untuk meikuti Pembelajaran yang diajarkan oleh guru.

Berdasarkan hasil analisis deskriptif hasil belajar matematika siswa kelas XI SMA Negeri 1 Ladongi menunjukan hasil perhitungan rata-rata hasil belajar matematika siswa tampak bahwa siswa yang mempunyai hasil belajar matematikayang baik yaitu yang tergolong dalam kategori baik dan sangat baik adalah sebanyak 59 siswa atau 93,66\% dan siswa yang mempunyai hasil belajar matematikayang kurang yaitu yang tergolong dalam kategori kurang dan cukup adalah sebanyak 4 siswa atau $6,34 \%$. Karena berdasarkan data yang diperoleh yaitu siswa yang mempunyai belajar baik lebih banyak dari siswa yang mempunya hasil belajar kurang, sehingga secara umum dapat dikatakan juga bahwa siswa kelas XI SMA Negeri 1 Ladongi mempunyai hasil belajar matematikayang baik.

Hasil temuan yang diperoleh dalam penelitian ini bahwa siswa kelas XI SMA Negeri 1 Ladongi mempunyai minat belajar pada mata pelajaran matematika yang baik dan hasil belajar matematikanya juga baik. Dari analisis desriptif yang dilakukan terlihat bahwa adanya hubungan antara minat belajar dan hasil belajaryaitu haldi peroleh dari hasil belajar yang baik dan minat belajar yang baik.Karena hasil belajar matematika siswa baik dan diikuti minat belajar siswa juga baik sehingga peneliti memeperoleh bahwa jika hasil belajar matematika siswa agar meningkat maka minat belajar siswa juga harus ditingkatkan untuk memperoleh hasil yang lebih baik.

Berdasarkan hasil uji hipotesis hubungan minat belajar dengan hasil belajar matematika diperoleh nilai signifikansi sebesar 0,000. Karena nilai signifikansi $0,000<\alpha$ (dimana $\alpha=0,05$ ), maka $\mathrm{H}_{0}$ di tolak. Dengan demikian minat belajar memiliki hubungan positif yang signifikan dengan hasil belajar matematika.Artinya, semakin tinggi minat belajar siswa, maka semakin tinggi hasil belajar matematika.sebaliknya, semakin rendah minat belajar siswa maka semakin rendah hasi belajar matematika siswa.Hubungan positif tersebut ditunjukan oleh nilai $\mathrm{R}$ pada uji signifikansi koefisien korelasi yaitu sebesar 0,687 yang bernilai positif.

Hal ini sejalan dengan Wasti (2013:3)
yang mengemukakan bahwa untuk meningkatkan hasil belajar siswa, salah satunya adalah menumbuhkan semangat minat belajar itu sendiri, karena dengan adanya minat belajar akan turut serta mengalami proses pemebelajaran yang berlangsung. Dengan berusaha mengetahui proses dalam mempelajari materi pelajaran, sedikit banyak akan menumbuhkan minat pada siswa untuk lebih meningkatkan hasil belajar yang diperoleh dari ujian yang diberikan. 
Ini membuktikan bahwa hasil belajar siswa yang baik di peroleh melalui minat belajar siswa yang muncul besar.Sejalan dengan pendapat Parnawi (2019) bahwa faktor-faktor yang mempengaruhi hasil belajar salah satunya ialah minat. Maksud dari minat tersebut ialah bagaimana cara guru membentuk minat siswa dalam melaksanakan proses pembelajaran atau menumbuhkan minat siswa sesuai dengan tujuan sekolah. Contohnya, jika tujuan sekolah untuk memebentuk siswa yanng mempunyai hasil belajar yang tinggi dalam mata pelajaran matematika, maka guru akan terlebih dahulu menarik perhatian siswa, untuk menarik perhatian siswa dalam belajar matematika guru dapat menjelaskan beberapa keuntungan menguasai ilmu matematika. Walaupun tidak semua siswa akan tertarik atau berminat belajar matematika, tetapi dengan pembiasaan, perhattian dan sugesti-sugesti yang positif, maka siswa akan terbiasa.

Berdasarkan hasil uji hipotesis tersebut juga diperoleh koefisien korelasi $\left(\mathrm{r}_{\mathrm{xy}}\right)$ sebesar 0,687 yang berdasarkan tabel 3.6 memiliki hubungan yang kuat dengan nilai koefisien determinasi sebesar 0,471 yang berarti bahwa besar hubungan antara minat belajar dengan hasil belajar sebesar 47,1\%. Besar hubungan minat belajar dalam meningkatkan hasil belajar matematika siswa ini dapat dilihat cukup besar yaitu hampir mendekati setengah dari faktor faktor lain yang dapat mempengaruhi hasil belajar sehingga diharapkan hendaknya sekolahdapat mempertahankan minat siswa dan juga lebih baik dapat meningkatkan minat belajar siswa yang sehingga dapat bermanfaat dan menjadi nilai tambah serta dapat menerapkan keterampilan yang telah dipelajari untuk lingkungan masyarakat sekitarnya. Sehingga siswa dapat memperoleh hasil belajar yang baik dan siswa dapat menerapkannya dalam kehidupan sehari-hari dikarnakan matematika besar kaitannya dalam kehidupan sehari-hari.

\section{Simpulan dan saran}

\section{Simpulan}

Berdasarkan hasil penlitian yang diperoleh penulis dan sesuai dengan rumusan masalah yang ada, maka penulis mengambil kesimpulan sebagai berikut.
1. Minat belajar siswa pada mata pelajaran matematika kelas XI SMA Negeri 1 Ladongi yang dikatakan baik yaitu sebanyak 52 siswa atau $82,54 \%$ dan siswa yang minat belajarnya kurang yaitu sebanyak 11 siswa atau $17,46 \%$.

2. Hasil belajar matematika siswa kelas XI SMA Negeri 1 Ladongi yang dikatakan baik yaitu sebesar 59 siswa atau $93,66 \%$ dan siswa yang hasil belajar matematikanya kurang yaitu sebesar 4 siswa atau $6,34 \%$.

3. Terdapat hubungan yang positif dan signifikan antara minat belajar dengan hasil belajar matematika siswa kelas XI SMA Negeri 1 Ladongi. Hubungan positif tersebut ditunjukan oleh nilai $\mathrm{R}$ pada uji signifikansi koefisien korelasi yaitu sebesar 0,687 yang bernilai positif dan signifikansi ditunjukan oleh uji signifikansi koefisien korelasi sebesar $0,000<\alpha$ (dimana $\alpha=0,05$ ). Serta besarnya hubungan antara minat belajar dengan hasil belajar matematika adalah $47,1 \%$ dan besar koefisien korelasi adalah 0,687 yang menunjukan kedua variabel mempunyai hubungan yang kuat.

\section{Saran}

Dengan adanya hubungan yang positif dan signifikan minat belajar terhadap hasil belajar matematika, maka diharapkan kepada:

1. Pihak sekolah sebaiknya melakukan upayaupaya untuk mengontrol minat belajar siswa dalam menghadapi mata pelajaran matematika misalnya dengan membuat kegiatan kegiatan yang menunjukan matematika itu menyenangkan dan sebagainya.

2. Guru khususnya guru bidang studi matematika yang sebaiknya selalu memperhatikan dan mendapat perhatian siswa sehingga minat belajar siswa terhadap mata pelajaran matematika besar. Upaya yang dapat dilakukan antara lain: guru meningkatkan kemampuan mengajarnya, lebih memahami karakter siswa masingmasing, menyesuaikan metode pengajaran sehingga akan menciptakan kondisi kelas yang menimbulkan minat belajar siswa besar.

3. Siswa sebaiknya mampu mengontrol minat belajar mereka saat menerima mata pelajaran matematika yang di berikan oleh guru. Salah satu upaya yang dapat dilakukan 
yaitu mengikuti pelajaran dengan sungguhsungguh dan memperbanyak menyelesaikan soal latihan sehingga memberikan dampak baik dalam meningkatkan hasil belajar matematika.

4. Bagi peneliti selanjutnya, hasil penelitian ini dapat digunakan sebagai bahan perbandingan untuk melakukan penelitian berikutnya dan peneliti juga menyarankan untuk mengambul vasiabel bebas yang lain atau lebih dari variable yang telah peneliti ambil agar mendapatkan hasil penelitian yang lebih baik sehingga dapat di gunakan dalam meniningkatkan hasil belajar siswa.

\section{Daftar pustaka}

Amir, A. (2014).Pembelajaran Matematika Sekolah Dasar Dengan Menggunakan Media Manipulatif.In Forum Paedagogik.6(1), 72-89

Arifin,S.(2018).Pengaruh Minat Dan Kreativitas Belajar Matematika Terhadap Hasil Belajar Siswa Kelas X. Histogram: Jurnal Pendidikan Matematika. 2(1),.59-70.

Aritonang, K, T. (2008).Minat dan Motivasi dalam Meningkatkan Hasil Belajar Siswa.Jurnal Pendidikan Penabur.7(10), 11-21.

Depdiknas.(2006). Permendiknas No 22 Tahun 2006 Tentang Standar Isi. Jakarta: Depdiknas.

Ditjen Dikdesmen. (2017). Panduan Penilaian oleh Pendidik dan satuan Pendidikan SMA. Jakarta: Direktotar Pembinaan SMA Ditjen Pendidikan Dasar dan Menengah.

Emda, A. (2017). Kedudukan Motivasi Belajar Siswa Dalam Pembelajaran. Lantanida Journa,5(2), 93-196.

Fajriani, N. I. (2017). Hubungan Minat Belajar dengan Hasil Belajar Matematika(Penelitian Koretarif pada Siswa Kelas VIIIC Semester Ganjil SMP Negeri 3 Sawit Tahun Ajaran 2016/2017.Skripsi, tidak diterbitkan, Program Sarjana Pendidikan Matematika Universitas Muhamadiyah Surakarta.
Faridisa, M, Sulistio, M, \& Ayu, Y. A. (2018).Penggunaan Aplikasi Geogebra pada Pembelajaran Matematika Materi Poligon Dan Sudut Sebagai Sarana Meningkatkan Kemampuan Siswa.Jurnal Equation. 1(2), 166-172.

Gasong, D. (2018). Belajar dan Pembelajaran. Yogyakarta: Budi Utama.

Jihad.(2012). Evaluasi Pembelajaran. Yogyakarta: Multi Pressindo

Kusumawardani, N. (2014).Korelasi antara Minat Belajar dengan Kedisiplinan Belajar Mata Pelajaran Matematika Siswa SD Kelas IV SD Negeri 1 Srobyong UPTD DIKPORA Kecamatan Milonggo, Jepara.Skripsi, tidak diterbitkan, Program Sarjana Pendidikan Guru Sekolah Dasar Universitas Muhammadiya Surakarta.

Lestari, K, E, \& Yudhanegara, M, R. (2015). Penelitian Pendidikan Matematika ( Panduan Praktis Menyusun Skripsi, Tesis dan Laporan Penelitian dengan Pendekata Kuantitatif, Kualitatif, dan Kombinasi Disertai dengan Model Pembelajaran dan Kemampuan Matematis). Refika Aditama. Bandung.

Pangestu, D, A, Samparadja, H, \& Tiya, K. (2015).Pengaruh Minat Terhadap Hasil Belajar Matematika Siswa Sma Negeri 1 Uluiwoi Kabupaten Kolaka Timur. Jurnal Pendidikan Matematika. 3(2).1726.

Pusdiklat Pegawai. (2016). Modul Penilaian Hasil Belajar. Depok: Pusdiklat Pegawai Kemendikbud.

Rusmiati.(2017). Pengaruh Minat Belajar Terhadap Prestasi Belajar Bidang Studi Ekonomi Siswa MA Al Fattah Sumbermulyo. Jurnal Ilmiah Pendidikan dan Ekonomi.1(2), 21-36.

Sari, F.K., Rakimahwati.,\& Fitria, Y. (2017) Hubungan Minat Dengan Hasil Belajar Peserta Didik Pada Pembelajaran Matematika Kelas VI SDN 25 Jati Tanah Tinggi. Jurnal Basicedu. 3(2).397-405.

Sidik.(2015). Analisis Peran Dosen Pembimbing Akademik (Pa) Terhadap Peningkatan 
Motivasi Dan Minat Belajar Mahasiswa.Widya Cipta. 7(2), 49-57.

Simbolon, N. (2014). Faktor-faktor yang Mempengaruhi Minat Belajar Peserta Didik.Elementary School Journal Pgsd Fip Unimed,1(2), 14-19.

Slameto.(2003). Belajar Dan Faktor-Faktor Yang Mempengaruhinya.Jakarta: Rineka Cipta.

Sriyanto, H. J. (2017). Mengobarkan Api Matematika. Bandung: Jejak.

Suardi, M. (2018).Belajar dan Pembelajaran. Yogyakarta: Deepublish.

Sughiarti, S. L. M. (2016). Hubungan Minat Belajar Dengan Hasil Brlajar Pada Siswa Kelas V Sekolah Dasar Gugus Wijaya Kusuma Ngaliyan
Semarang.Skripsi.Tidak

diterbitkan.Program Sarjana Pendidikan Guru Sekolah Dasar Universitas Negeri Semarang.

Syah, Muhibbin. (2010). Psikologi Belajar.Jakarta : Rajawali Pers.

Wahab, Rohmalina. (2015). Psikologi Belajar. Jakarta: Raja Grafindo Persada.

Wahyuningsih, E.S.(2020).Model Pembelajaran Mastery Learning Upaya Peningkatan Keaktifan Dan Hasil Belajar Siswa. Yogyakarta: Deepublish.

Wasti, S. (2013).Hubungan Minat Belajar Dengan Hasil Belajar Di Madrasah Aliyah Negeri 2 Padang. E-Journal Home Economic and Tourism.2(1). 114 